\title{
Uma história de cinema e censura durante a ditadura brasileira:entrevista com Tereza Trautman
}

\author{
Ana Maria Veiga \\ Universidade Federal de Santa Catarina
}

\begin{abstract}
Resumo: O trabalho da cineasta Tereza Trautman foi perpassado pela emergência das reivindicações de emancipação e igualdade para as mulheres, principalmente na década de 1970. Enquanto o governo militar brasileiro e seu órgão de censura tentavam moralizar a sociedade e manter as mulheres em seus papéis privados, tradicionalmente estabelecidos, Tereza Trautman pegou a câmera e buscou criar novas representações para elas no cinema. De maneira radical, seu trabalho adquiriu agenciamento, questionando de modo irreversível o lugar das mulheres, na proposta de uma nova sociedade. A tesoura da censura atravessou definitivamente sua carreira e a cineasta viu, um após o outro, seus projetos profissionais naufragarem. Os homens que eu tive, seu filme mais polêmico, está no centro do interesse desta entrevista, que abre espaço para uma narrativa, que é também um desabafo de uma geração de mulheres que buscaram estratégias de sobrevivência profissional e de expressão durante os anos de ditadura.

Palavras-chove: Tereza Trautman; Os homens que eu tive; cinema; ditadura.
\end{abstract}

Tereza Trautman dirigiu filmes nos anos 1970 e 1980, tendo a carreira profissional fortemente confrontada com o regime militar brasileiro. Em 1972, aos 21 anos de idade, fez o roteiro e começou a produzir seu primeiro longa-metragem, que intitulou Os homens que eu tive. A película, lançada e depois interditada pela censura em 1973, interpelava o contexto repressivo, ao mesmo tempo em que dialogava com a emergência do movi-

(c) $(0)$ Esta obra tem licença Creative Commons 
mento feminista no Brasil e na América Latina, na esteira das manifestações globais. Como partes desse movimento, diversas mulheres em vários países tomaram as câmeras e começaram a dirigir seus próprios filmes, adentrando um meio quase que exclusivamente reservado aos homens. Entre elas estava Tereza Trautman - a grande surpresa da cena nacional naquele momento.

Os homens que eu tive narrava a história da personagem Pity, uma mulher casada, ${ }^{1}$ de classe média e da zona sul carioca, que vivia um triângulo amoroso, com o consentimento do marido, Dôde. Depois do convite feito ao namorado Sílvio, para morar no apartamento do casal, Pity segue ainda com outras relações amorosas, dando asas aos seus desejos, em transas ou paixões, demonstrando total liberdade de escolha e de direito a seu próprio corpo - um dos lemas do movimento feminista. A maior prova disso é a cena final do filme, quando Pity - desta vez em outro triângulo, com Torres e o marido Dôde informa a seus dois parceiros que está grávida. Diante da pergunta sobre de quem seria o filho, ela responde com simplicidade: "É meu."

No decorrer da trama, Pity vai se dando conta de que a relação heterossexual de certo modo desfavorecia as mulheres, sempre tolhidas em sua liberdade por regras e padrões de conduta. Os homens que eu tive estreou com sucesso em julho de 1973 e foi recolhido dois meses depois. Apesar das diversas tentativas de liberação, por parte da cineasta e da produtora Herbert Richers - registradas em 28 documentos da censura federal - o filme permaneceu interditado até 1980, ano em que foi relançado, de maneira descontextualizada, ${ }^{2}$ e acolhido em meio a outros tipos de discussão. ${ }^{3}$

O filme de Tereza Trautman remete-nos a diversas questões, que são constantemente debatidas na teoria feminista do cinema, como a autoria feminina, o chamado "cinema de mulheres" e a representação das mulheres nos filmes.

Teresa de Lauretis, por exemplo, argumenta que o paradoxo que acompanha o desenvolvimento do pensamento feminista

\footnotetext{
' Percebi, durante a pesquisa nos documentos da censura sobre o filme (Ana Maria VEIGA, 2013, p. 200), que o fato de a protagonista ser casada era o que mais incomodava os censores. Se Pity fosse uma prostituta e tivesse diversos relacionamentos, ela estaria no lugar adequado. Assim como a personagem Geny, interpretada pela mesma atriz, Darlene Glória, no filme Toda nudez será castigada, de Arnaldo Jabor. Retornaremos ao filme de Jabor mais adiante.

${ }^{2}$ Percebemos isso nos recortes dos jornais do período, encontrados na Cinemateca Brasileira, em que alguns críticos qualificam o filme desta maneira: "Simpático, simples, direto. E levemente ingênuo". Comentário publicado no Jornal da Tarde, em 18 de agosto de 1980 (VEIGA, 2013, p. 205), desconsiderando que a obra foi realizada dentro do contexto de sete anos passados em pleno confronto com a fase mais severa da ditadura militar.

${ }^{3} \mathrm{Em}$ 1980, já podíamos acompanhar pela televisão as discussões semanais trazidas pelo quadro de Marta Suplicy sobre sexualidade na TV Mulher e também nos episódios da série Malu Mulher - ambos produções da Rede Globo.
}

840 Estudos Feministas, Florianópolis, 23(3): 839-860, setembro-dezembro/2015 
ecoa uma contradição específica, talvez constitutiva do próprio movimento, que esteve no centro dos debates sobre o "cinema de mulheres", sua política e sua linguagem. Assim, essa, contradição foi articulada dentro da teoria fílmica anglo-americana no início dos anos 1970: na relação com a política feminista e o movimento de mulheres, por um lado, e, por outro, nas práticas da vanguarda artística e da realização fílmica das cineastas. De acordo com a autora, a cultura fílmica feminista, a partir da metade da década, tendia a enfatizar a dicotomia entre as preocupações do movimento de mulheres e o trabalho cinematográfico, que pareciam estranhos um ao outro. O movimento clamava pela documentação imediata das propostas de ativismo político, pelo aumento de consciência e pela expressão própria ou busca de "imagens positivas" de mulheres; o meio profissional insistia no rigor formal - sendo o aparato cinematográfico compreendido como "tecnologia social" - para analisar e desengajar códigos ideológicos infiltrados na representação. ${ }^{4}$

Anneke Smelik ${ }^{5}$ explicita a necessidade de se considerar a subjetividade feminina no cinema, com a presença de mulheres espectadoras e diretoras. A autora percebe as diretoras feministas como mulheres e sujeitos feministas. Nas palavras de Smelik, "Um sujeito tem agência e escolha, mas também desejo. Portanto, quero distinguir e reconhecer esses dois registros na subjetividade feminina que podem mutuamente se informar e reforçar: o desejo e a fantasia, de um lado, e o poder de decidir e a agência de outro". 6 Para ela, o posicionamento como mulher é o que levaria a uma mudança na representação da subjetividade feminina no cinema. ${ }^{7}$ Mas essa agência poderia se mostrar das maneiras mais diversas. ${ }^{8}$

Situando a obra de Tereza Trautman no contexto latinoamericano, encontramos os dois curtas-metragens da cineasta argentina María Luisa Bemberg - Femimundo, el mundo de la mujer, de 1972, e Juguetes, de 1978 - e o longa-metragem da cubana Sara Gómez - De cierta manera, de 1974. Bemberg e Gómez problematizaram também o que na época chamou-se "condição feminina" - termo trazido por Tereza Trautman nesta entrevista -, fazendo em seus filmes a crítica de costumes que encontramos como pano de fundo nos trabalhos da brasileira.

\footnotetext{
${ }^{4}$ Teresa de LAURETIS, 2007, p. 25-26.

${ }^{5}$ Anneke SMELIK, 1998, p. 29.

${ }^{6}$ No original: "A subject has agency and volition, but also desire. I therefore want to distinguish and recognize these two registers in female subjectivity that can mutually inform and reinforce each other: of desire and fantasy on the one hand and of will and agency on the other". Tradução minha.

${ }^{7}$ SMELIK, 1998, p. 32.

${ }^{8}$ O conceito de "agência" também é trazido por Sherry ORTNER (2006), antropóloga feminista, ao explorar a intencionalidade dos sujeitos e sua relação com o poder. Agência diz respeito ao empoderamento dos agentes nas relações sociais. Quanto mais poder, mais agência eles terão.
} 
Antes de the passar a palavra diretamente, trago uma fala sua, retirada de um congresso sobre autoria feminina no cinema. ${ }^{9}$ Nela, Tereza conta que estava dirigindo seu primeiro filme, o curta-metragem Curtição, um dos episódios do longa intitulado Fantasticon, quando se deparou com a insubordinação do cinegrafista - homem e mais experiente do que ela no meio cinematográfico. Quando a diretora deu o comando "ação" - palavra que determina o início da filmagem -, o profissional baixou a câmera, deixando claro que não a operaria. A resposta de Tereza foi a tomada do pesado equipamento em suas aparentemente frágeis mãos; assim, ela rodou toda a cena. No final, devolvendo o equipamento a ele, finalizou: "Nunca mais faça isso." A imagem que emerge desta memória indica-nos um caminho marcado pela determinação, passando sobre a ordem do gênero, culturalmente estabelecida.

A trajetória desta diretora oferece-nos um mergulho no mundo do cinema, para além de seus mitos e glamour. É uma narrativa sobre o trabalho árduo, necessário em um meio de comunicação que é um dos grandes palcos das disputas ideológicas. Tereza Trautman sabe e afirma: "Se eu fosse um homem, eu teria tido apoio para livrar o filme da censura" assim como outros cineastas tiveram. ${ }^{10}$ Vemos com ela a inserção e a descoberta do movimento feminista, do qual participou ao lado da amiga Rose Marie Muraro.

Hoje, Tereza dirige um pequeno canal de televisão que exibe apenas filmes brasileiros e estimula a produção de trabalhos com caráter social. ${ }^{11}$

O encontro com Tereza Trautman aconteceu no dia 13 de maio de 2010, quando realizei com ela esta primeira entrevista. Naquele momento eu pesquisava diretoras de cinema que fizeram filmes durante a ditadura brasileira. ${ }^{12}$ Outros contatos e diálogos vieram depois, complementando as informações sobre sua vida e trajetória profissional.

Ao(à) leitor(a) do texto que apresentaremos a seguir está interditada a visão de seus olhos vibrantes e uma relação direta com a vitalidade de sua memória, diante de cada desafio por ela enfrentado. Escolhemos publicar esta entrevista por entendêla como a mais completa, mas oferecemos também alguns

\footnotetext{
9 Colóquio Brasileiro Cinema de Autoria Feminina I, realizado em novembro de 2014, na Universidade Federal de Juiz de Fora.

${ }^{10}$ Retornamos aqui a Toda nudez será castigada, de Arnaldo Jabor - filme que foi interditado em 1972, mas que em 1973 já circulava livremente nas salas de cinema e em festivais, e cujos produtores já pediam autorização para sua exibição na TV. De conteúdo erótico mais explícito do que o filme de Tereza Trautman, o filme de Jabor encontrou um caminho até as graças da liberação (VEIGA, 2013).

${ }^{11}$ Trata-se do Cine Brasil TV, no ar no sistema fechado de televisão.

${ }^{12}$ Optei por três delas para trabalhar na tese que denominei Cineastas brasileiras em tempos de ditadura - cruzamentos, fugas, especificidades. Trata-se de Tereza Trautman, Helena Solberg e Ana Carolina.
}

842 Estudos Feministas, Florianópolis, 23(3): 839-860, setembro-dezembro/2015 
dados complementares, colhidos em conversas e eventos dos quais participamos juntas. ${ }^{13}$

Elaborar uma entrevista é sempre estimulante. Diante da fluidez e da clareza de ideias dessa entrevistada, optei por explicar a ela o que pretendia e então deixar que expressasse sua versão da história que viveu, ${ }^{14}$ apenas pontuando e direcionando algumas questões.

\footnotetext{
${ }^{13}$ Como o II Colóquio Internacional Gênero, Feminismos e Ditaduras no Cone Sul, realizado de 11 a 14 de agosto de 2014, na Universidade Federal de Santa Catarina, e o I Colóquio Brasileiro Cinema de Autoria Feminina, realizado de 10 a 12 de novembro de 2014, na Universidade Federal de Juiz de Fora.

${ }^{14}$ Considerando a multiplicidade de olhares e interpretações sobre uma mesma história ou um mesmo evento, entendo a "narrativa de si" de Tereza Trautman como uma versão de sua própria trajetória de vida, permeada por sentimentos, ressentimentos e esquecimentos. Uma autora e um autor que podem auxiliar na compreensão de tal complexidade são Luzia Margareth RAGO, 2013, e Paul RICOEUR, 2008.
} 
${ }^{15}$ José Celso Martinez, conhecido diretor do teatro brasileiro.

${ }^{16}$ Cineasta e escritor, filho de Oswald de Andrade e Patrícia Galvão (Pagu).

${ }^{17}$ Diretor de teatro.
18 Professora universitária e atriz de teatro, conhecida pelas gerações mais recentes pelo audiovisual "Tapa na Pantera" divulgado pela web.
Ana Maria Veiga (AMV): Tereza, fale um pouco sobre a relação entre ditadura, censura, seu trabalho e o filme interditado, Os homens que eu tive.

Tereza Trautman (TT): Olha, eu tinha 17 anos em 1968, estudava no Colégio de Aplicação da USP. Eu passei do científico para o clássico, exatamente porque eu queria fazer cinema. A gente tinha sessões de domingo num cinema do bairro, que a gente fazia no próprio cinema às 10 horas da manhã. Então, assisti a filmes maravilhosos. Foi assim que eu conheci $A$ hora e a vez de Augusto Matraga, Vidas secas, foi assim que eu vi Masaki Kobayashi... E, no colégio, a gente trazia o Zé Celso, ${ }^{15}$ o Rudá de Andrade, ${ }^{16}$ o Silnei Siqueira ${ }^{17}$ não vou lembrar o nome de todos - para fazerem workshops conosco no colégio. E a minha ideia era ir para a Universidade de Brasília. Com o Al-5, veja... ele pegou a nossa trajetória assim e estraçalhou. Muitos da própria turma foram presos, professores presos, outros iam para outro país... Eu ia para a Universidade de Brasília, mas ela fechou, foi invadida.

Eu venho de família pobre, família de operários, então eu trabalhava desde os 15 anos de idade. Aos 17 anos, quando foi o ano da efervescência, da ocupação da Maria Antônia e tudo, eu como aluna do Colégio de Aplicação da USP - colégio secundário que era da Faculdade de Filosofia da USP, na rua Maria Antônia -,o pessoal do movimento estudantil me procurava para eu bater o boletim direto no estêncil. Eram dois boletins diários: um mais ou menos às duas da tarde e um mais ou menos sete e meia, oito da noite; eram boletins da ocupação, dando conta para todo mundo do que estava acontecendo. Então, como é que era feito o boletim? Pessoas de todas as facções sentavam e discutiam o problema e eu digitava. Eles, às vezes, discutiam e mudavam de opinião. Eu tinha que escrever... Eu mesma olho para trás e penso: como eu conseguia? E o pessoal me procurava porque, além de eu bater muito bem, muito rápido, como eu já trabalhava, eu conseguia tirar a síntese do que as pessoas estavam discutindo para deixar as pessoas informadas. Então, sempre era: "Tereza! Cadê a Tereza?"

Eu fiz nessa época um curso de teatro. Minha professora no Aplicação, de teatro, era Maria Alice Vergueiro. ${ }^{18}$ Então, o Zé Celso era convidado, o Silnei, tudo através dela. Ela que trazia e acompanhava. Eu já acompanhava uns filmes que estavam sendo feitos, eu queria ser continuísta. Quando os filmes estavam em preparação, eu acompanhava e falava: "Eu posso ser a continuísta?" [risos] E fazia curso de formação em teatro com o Eugênio Kusnet, com a Miriam Muniz.

Cheguei a ganhar um rolo de $16 \mathrm{~mm}$ de negativo para fazer um filme nessa época, de presente. E eu acabei devolvendo o rolo inteiro do negativo e disse: "Não, isso você dá para alguém fazer, porque eu não tenho como fazer em $16 \mathrm{~mm}$, porque é um equipamento que eu não disponho. E eu vou tentar fazer com 35

844 Estudos Feministas, Florianópolis, 23(3): 839-860, setembro-dezembro/2015 
$\mathrm{mm}$ ". Todo mundo me olhou, assim, com o olho arregalado. Antes de eu completar 19 anos, nasceu meu primeiro filho e eu comecei a fazer o meu filme. Compramos um negativo fotográfico vencido, na Fotoptica. Eu tinha feito curso de fotografia cinematográfica também. O rolo era de 30 metros. Só para você ter uma ideia, representa um minuto de cinema. Então fizemos testes para ver qual era a margem de tolerância que o negativo tinha, se estava ainda usável. Estava sem numeração de borda, isso foi um terror que a gente enfrentou depois. Pegamos o equipamento emprestado. O negativo foi pago graças ao meu fundo de garantia. Como eu trabalhava, estava de licença maternidade. Pedi demissão assim que acabou a licença, retirei meu fundo de garantia e paguei o negativo. Pegamos a câmera emprestada com Primo Carbonari e fizemos um filme de episódios chamado Fantasticon. Foi o último filme preto e branco a ser exibido. Foi lançado comercialmente e foi assim que eu vim para o Rio de Janeiro, no lançamento desse filme.

AMV: Isso em 1970?

Tा: Em 70. Eu vim para o Rio de Janeiro e produzi outros filmes. No Fantasticon, eu tive que aprender a fazer tudo, foi meu filme escola. Como não pude ir para nenhuma escola - tinha a escola da São Luís nessa época, mas era paga -, eu estudava cinema nos livros. Tinha feito fotografia cinematográfica, direção de atores... Então eu falei: "Não, eu não vou poder ficar, parar, estudar...", então eu aprendi a fazer o filme fazendo, tudo foi feito, a mixagem foi feita.

AMV: A montagem toda?

Tा: A montagem toda, mas a mixagem nós fizemos, e depois fizemos a transferência do magnético, o tape, para o ótico, direto.

AMV: E deu certo?

Tा: Quem montou o negativo? Eu aprendi a montar o negativo, cada um montou o do seu episódio. O Oswaldo Kemeny era dono da Rex Filme - figura maravilhosa do cinema brasileiro -, eu entrava quando os funcionários dele saíam, seis da tarde, e saía quando os funcionários dele chegavam, às sete da manhã. Passava a noite trabalhando no equipamento lá dentro do laboratório, e elas (as funcionárias) me ensinaram a montar o negativo, porque o filme, por ser fotográfico, não tinha numeração de borda. É um número que tem, sequenciado, a cada pé. Só que sem numeração de borda, como é que você sabe em que altura está para colocar negativo com positivo? Para você vir montando? Garota, olha...

AMV: Foi a melhor escola, não é?

Tा: Eu aprendi, foi minha escola, foi minha formação. Aprendi ali. E esse filme ganhou crítica. Eu lembro que eu tinha uma crítica 
do José Carlos Avelar, mas quando fui procurar, alguém tinha jogado fora. Ganhou matéria, porque eu cheguei na Folha de São Paulo com o release que eu mesma tinha batido e mimeografado. A Folha era um conglomerado, Folha da Tarde, Notícias Populares, Folha da Noite, havia vários jornais ali naquele prédio. Então eu lembro que eu fui lá e falei: "Eu gostaria que vocês abrissem um pouquinho de espaço para o meu filme". Eles disseram: "Ah, o seu filme, o que você fez? Qual o papel?" Eu disse: "Não, eu escrevi, dirigi, produzi..."E eles: "O quê? Como?" A primeira entrevista que eu dei na minha vida foi uma coletiva de imprensa, porque todos os jornais, todo mundo dizia: "O quê? Como? Você fez isso? Você sabe que não tem nenhuma outra mulher fazendo isso?" Eu falei: "Nunca me dei conta disso, eu estou fazendo porque é a profissão que eu escolhi e é isso o que eu vou fazer. Eles ficaram assim... [de boca aberta]. "Eu trabalho desde os 15 anos, trabalhar para mim não tem segredo." Bom, sabe aquela coisa assim, quando as pessoas param, tudo para? Eu falei: "Mas não é possível." E eles: "Você tem ideia do que você fez?" Eu respondi: "Sim, eu sei o quanto de trabalho isso me deu, como isso é trabalhoso. Fazer um filme custa muito caro e é um ato de desprendimento muito grande e se não fosse o Primo Carbonari, que cedeu todo o equipamento de graça, a gente não teria feito esse filme". Porque ele cedeu equipamento de filmagem, montagem, revelou o ótico, fez a mixagem ali no estúdio, se não fosse ele, a gente não teria feito. Para mim tudo era tão normal, depois do trabalho...

AMV: Para você era um trabalho, mas para eles tinha outra conotação, não é?

Tा: Para eles era uma coisa caída do céu, porque eles não tinham ideia; no meio da ditadura, uma coisa dessas. O filme foi lançado comercialmente em 1971. Isso foi em 71, eu tinha 20 anos de idade.

AMV: E, no caso, abertamente, uma mulher fazendo cinema.

Tा: Nunca tinha me passado isso [aponta para a cabeça e ri]. Só depois é que eu fui conhecer a história, porque aí eu vim para o Rio de Janeiro produzir um filme, o produtor tinha dado uma câmera que tinha um problema na grifa - grifa é aquilo que puxa - e o negativo saiu todo corrido, e nós estávamos filmando em locação. Manda o negativo, revela, devolve o negativo... Bom, quando a gente ficou sabendo que o filme estava com problema, já tinha três semanas de filmagem, quase praticamente o filme inteiro na lata. Tivemos que refazer.

AMV: Esse ainda era o primeiro?

Tा: Esse era o filme que eu fui produtora.

AMV: Agora fala um pouco então do seu filme, Os homens que eu tive.

846 Estudos Feministas, Florianópolis, 23(3): 839-860, setembro-dezembro/2015 
${ }^{19}$ Leila Diniz (1945-1972) morreu em um acidente aéreo quando sobrevoava Nova Delhi, voltando da Austrália para o Brasil quando iria iniciar as filmagens de Os homens que eu tive.
${ }^{20}$ Betty Friedan (1921-2006) visitou - Brasil para lançar seu livro $A$ mística feminina (Feminine Mystique) e difundir as discussõe do feminismo. Abro um parêntesis para dizer que o livro de Friedan (1963), inspirado em O segundo sexo, de Simone de Beauvoir (1949), trouxe a público a insatisfação das mulheres estadunidenses do pós-Segunda Guerra quando os homens voltaram às suas casas e ao mercado de trabalho, de onde elas tiveram que recuar e retornar à vida doméstica de cuidados com o lar (incluindo filhos e marido), de consumo e aparências.
Tा: Aí é que eu fiz, aí é que eu escrevi Os homens que eu tive. Eu falei: 'Ah, é? Essa coisa de 'as mulheres que eu tenho'... é assim? Então, para as mulheres também: 'os homens que eu tive'". Eu escrevi o roteiro e contratei a Leila Diniz, mas ela faleceu poucos dias antes de começar a filmar. E eu vi a despedida dela com a filha, sabe? Eu fui me despedir da Leila e ela estava se despedindo da filha e a filha querendo e querendo a mãe. Sabe? Uma bebezinha de meses de idade. A Janaína tinha uns seis meses, sete meses... e a morte da Leila foi um choque muito grande. ${ }^{19} \mathrm{E}$ o produtor do filme dizia para mim: "Nós temos que começar a rodar, isso pode acontecer com qualquer um." E eu em estado de choque, não conseguia olhar para o roteiro; cada pedaço do roteiro eu tinha trabalhado com a Leila, então já era a versão para rodar. Já tinha trabalhado com ela, já tinha discutido tudo. E eu estava... eu fiquei... bom... E o produtor: "Não é possível que não tenha outra atriz." Eu comecei a fazer teste com as atrizes, ai meu Deus do céu! E o produtor... [sobre] a Elke Maravilha - fiz teste com ela também: "Ótima, maravilhosa! Essa aí, então." Eu falei:"Não, eu sei o que tive que passar para tirar esse teste, eu não aceito." Adoro a Elke, acho ela uma maravilha, mas esse filme tem horas que é um drama light, como é que eu vou fazer? A Elke é solar feito a Leila, mas como é que eu vou fazer? Fiz teste com várias atrizes. O produtor, pior do que eu, não aceitava quase nenhuma delas: "Não, não, não. Ih, não! Essa aí não tem nenhum apelo... Essa outra não tem nenhuma empatia. Essa não vai." Bom, filmei com a Darlene Glória. Darlene era exatamente o oposto da Leila. Então, em vez de ser a mulher solar, eu tinha que falar com a Darlene - imagine, eu tinha 21 anos. E dizia a ela: "Darlene, não é Maria Madalena. Ela [Pity] não sente nenhuma culpa. Isso é o que ela tem vontade de fazer e ela vai fazer. Então não tem nenhuma carga nisso. Ela vai conversar, discutir as coisas com o marido, mas não é com carga." Bom, a Darlene me deu bastante trabalho, tive que mudar todo o elenco masculino, porque a Leila era mais jovem, então a idade do elenco todo era mais jovem. Eu passei a achar que a história não fazia mais sentido. Estava com muitas dúvidas... Leila era [seis anos] mais velha que eu, Darlene [quatro anos] mais velha que a Leila, então tinha um gap assim, enorme. E as dúvidas eram dúvidas minhas, eu que tinha escrito o roteiro, não é? Imagina... tive que reescrever tudo.

Não foi fácil, vamos dizer assim, porque isso foi em 1972. Não tinha nem Betty Friedan passado pelo Brasil ainda, ${ }^{20}$ entendeu? Não tinha ainda uma... [discussão sobre a emancipação das mulheres]. E eu achando o quê? A ditadura tinha me proibido de discutir a realidade social do país, mas havia uma questão privada, que era social, que era a "condição feminina", que eu ia discutir [risos]. Então, como é que você vai colocar isso, não é? 
${ }^{21}$ Cineasta. Um de seus filmes mais conhecidos é Zuzu Angel, de 2006

${ }^{22}$ Produtora, roteirista e atriz de cinema.
Eu não tive nenhum problema, nem com o produtor nem com a equipe, nem com o elenco. A Darlene falava assim: "Tereza, você tem mil anos de idade. Nossa, você é uma mulher que tem uma carga dramática, uma vivência..." E eu falava: "Legal, deixa o peso todo comigo e você fica leve, você tem que ficar light." Bom, lançamos o filme. Na noite de estreia do filme... naquela época não tinha nenhum convite, tá? Você simplesmente avisava: estreia do filme meia-noite no Roxy. O Roxy era um dos maiores cinemas do Rio de Janeiro, tinha mil e setecentos, mil e oitocentos lugares. Eu fui tão feliz para o cinema, que não levei documento e o porteiro não me deixava entrar [risos]. Nossa conversa foi assim: "Você tem documento, menina?" "Esqueci." "Como é que eu vou saber se você tem 18 anos?" "Eu tenho, fui eu que fiz esse filme." "Ah é? Conta outra." "Ai meu Deus! É lógico que fui eu que fiz!" "Ah tá bom, tá certo. Quando você lembrar quem você é, trouxer um documento, você entra. Sai, sai, sai, que a fila tem que andar." Meus amigos passavam e entravam no cinema e eu ali do lado de fora, pensando: "Meu Deus do céu, e agora?" Olha, com o filme já começado, o porteiro finalmente me deixou entrar e só tinha lugar para sentar na "torrinha", do lado do projetor, sabe? Lá em cima, na galeria, ali no meio da turma da bagunça. O cinema lotado. Olha, uma sensação que eu nunca tinha experimentado. As pessoas riam e a turma da bagunça começou a gritar coisas assim: "Bota a banana na bunda dela!" Sabe, aquelas coisas assim? O "filho" está no mundo, você não manda mais, não é? O filme acabou, desci correndo, naquela massa de gente, as pessoas saíam numa alegria... Eu não estava lá embaixo, não tinha nem escutado nada, eu estava lá onde estava a turma da bagunça. As outras pessoas estavam sentadas na plateia. E todo mundo: "Ah, que legal! Nossa, que maravilha o filme!" Bom, eu sei que um monte de gente ficou com vontade de fazer cinema quando viu meu filme. Até o Sérgio Rezende ${ }^{21}$ e a Mariza Leão, ${ }^{22}$ que estavam namorando nessa época, falaram: "A gente viu seu filme, a gente falou: a gente quer fazer filme assim." Porque é um filme em que você está discutindo o seu mundo, a sua realidade. Fazer um filme barato, é possível, e, ao mesmo tempo, que interesse ao público.

O filme foi um sucesso estrondoso, tá? E estava marcado para ser lançado em São Paulo juntando dois circuitos de exibição, coisa que na época era raríssimo, porque os exibidores sempre foram concorrentes que nem se falavam. Na segunda-feira do feriado de 7 de setembro, a Folha de São Paulo, que fazia sempre as melhores abordagens sobre os filmes da semana que iam entrar, publicou sobre ele. A capa da Folha llustrada era o meu filme. Mas ele foi interditado na quarta-feira, antes do feriado. Jamais estreou em São Paulo, quer dizer, estreou lá depois, 10 anos depois. O filme foi interditado devido à suposta denúncia de uma mulher de Belo Horizonte, que ligou para a Polícia Federal, falou com o

848 Estudos Feministas, Florianópolis, 23(3): 839-860, setembro-dezembro/2015 
${ }^{23}$ General Ernesto Geisel, presidente militar de 1974 a 1979.

${ }^{24} \mathrm{Em}$ 1964, em Recife, o veterano militante comunista, Gregório Bezerra, foi amarrado pelo pescoço, arrastado pelas ruas e espancado por um coronel do Exército em praça pública. Ver em: http: /arte.folha.uol.com.br/especiais/ 2014/03/23/o-golpe-e-a-ditaduramilitar/a-ditadura.html.
${ }^{25}$ Esta fala de Tereza é interessante para pensarmos o impacto da censura do filme em sua vida. Na memória da cineasta, a interdição, que perdurou de 1973 a 1980 , levou infinitos "dez" anos. A década de interdição não é uma década temporal convencional mas emotiva, sendo ao mesmo tempo histórica - no sentido dado por Reinhart KOSELLECK (2006) general Antônio Bandeira, que era o chefe da Polícia Federal na época, dizendo que estava passando um filme que "denegria" a imagem da mulher brasileira, que era um atentado contra a família. E o filme foi interditado. Só isso. Tirado de cartaz.

Tentou-se liberar o filme de todas as formas. Em 1974, assumiu o Geisel. ${ }^{23}$ Como o Antônio Bandeira tinha torturado o Gregório Bezerra $^{24}$ em praça pública, ele saiu correndo da Polícia Federal quando o Geisel entrou - porque o irmão do Geisel tinha sido contra o que ele tinha feito com o Gregório Bezerra. Ele saiu da Polícia Federal e logo assumiu, em seu lugar, o coronel Moacir Coelho. Eu fui para Brasília, passei uma semana lá para conseguir sentar e conversar com ele. Você não conseguia marcar, agendar e ir. Você tinha que ir lá, se apresentar, dizer a motivação e o que é que te levava, para você pedir a reunião. Ele olhou [o pedido] e disse: "Eu vou assistir ao filme." Assistiu ao filme e falou: "Sim, senhora." Porque o filme tinha sido liberado para 18 anos sem cortes, eu acho. Eu tenho até o certificado de censura. E ele disse: "Vamos fazer uns cortezinhos e a senhora vai ter o filme de volta. Não tem o menor sentido este filme estar interditado." Eu, feliz da vida: "Ai, que maravilha! Muito obrigada." Ele me disse isso pelo telefone. Nunca mais falou nada. Eu fiquei... uma semana, duas semanas, ligava para lá: "Estou esperando, estou aguardando, estou precisando. Isso é uma obra comercial". Aí o assessor disse: "É porque o coronel é coronel. Quem interditou é general, então há uma questão hierárquica que a gente não vai ter como resolver. A senhora tem que apelar para o ministro" [pausa prolongada, ela me olha]. E com o ministro, sequer tinha onde você apelar a liberação do filme. O filme só foi liberado dez anos depois. ${ }^{25}$ [silêncio, me olha fixamente]

AMV: Em 1983?

Tा: [buscando pela memória] Em 83, 83...

AMV: E teve que mudar de nome? [nos documentos da censura aparece também o título Os homens e eu]

Tा: A gente até ofereceu, vamos mudar de nome, mas nem assim. A gente ofereceu: "Você quer, a gente muda de nome, começa um novo procedimento, como se fosse um filme novo." Nada. Era como se você falasse com uma parede, não tinha resposta, não tinha retorno nenhum, sabe? Não dava para dar andamento [contrariada]. Se tentou de todas as formas na época. Somente depois é que se conseguiu liberar o filme, porque não fazia o menor sentido o filme estar interditado, não tinha uma cena, não tinha nada. Era o contexto.

AMV: A gente pode dizer que a ideia de liberação das mulheres incomodava a ditadura?

Tा: Eu acho que não era bem o que eles queriam que aconte- 
cesse, não é? Acho que já era uma coisa muito subversiva, porque, imagina... agora ainda as mulheres! E eu posso dizer com toda a certeza, eu posso te afirmar, porque grande parte eu vi, muitos intelectuais irem contra o movimento de emancipação das mulheres, tá? Muitos muito conhecidos, que falaram textualmente. A gente se reuniu, por exemplo, para fazer uma semana da mulher em 1975 - quando a ONU decretou o Ano Internacional da Mulher -, cineastas homens passando, falando: "Ah, quer dizer então que agora vai ter também o movimento dos negros, dos índios..." [ri ironicamente] Então, eu sei que não era uma coisa que as pessoas viam com bons olhos ou que levavam a sério. E a gente sabe que houve um grande retrocesso, eu acho, nesses últimos anos, um grande retrocesso, mas eu acho que todo mundo sabe que foi da maior importância ter havido essa emancipação da condição que nós tínhamos no país.

Eu lembro, por exemplo, com 18 anos não conseguia tirar 0 dinheiro do meu trabalho no banco, eu tive que fazer um escândalo, isso foi dentro do banco Itaú. Eu discuti com o atendente: "Esse dinheiro eu ganhei com o meu trabalho." "Ah, mas você tem 18, com 18 anos você não pode ter conta em banco." "Como que eu não posso ter conta em banco? Sou casada." "Ah, então seu marido." "Como o meu marido? É meu dinheiro, não é o dinheiro dele." Eu fiz um escândalo, eu não sabia dessas questões. Eu tinha na época exatamente 18 anos e não queriam deixar. Então você vê como a situação feminina nessa época era de subordinação, ou ao pai ou ao marido, a mulher era tutelada.

Eu venho de uma família onde homens e mulheres faziam o trabalho fora de casa e dentro de casa. Eu jamais via diferença entre homem e mulher, na minha infância, na minha adolescência, não via. Eu achava que as mulheres faziam trabalhos que eu achava horríveis, mas eu não tinha nem tempo de fazer esses trabalhos, porque, como eu estudava o dia inteiro, depois trabalhava, eu não tinha tempo. Eu só olhava aquilo ali e achava que era uma prisão, achava um trabalho muito enfadonho, sabe? Mas não me passava, porque o meu avô, por exemplo, teve um [filho] homem, que foi meu pai, e cinco mulheres. Meu avô acordava de manhã, meu pai já era casado e havia três mulheres com ele em casa. Eu era pequena e eu via isso. $O$ meu avô acordava, fazia o café da manhã, punha a mesa, enquanto elas se aprontavam. Chamava todas para o café da manhã e ele, enquanto elas terminavam de se aprontar, tirava a mesa e lavava a louça. Então, como é que eu podia imaginar que as coisas eram... Não, as coisas tinham outra partição de trabalho, entendeu? E a minha madrinha, que era uma das filhas do meu avô, ela falou:"Eu também não tinha ideia. Quando eu me casei e o meu marido não lavava a louça do café da manhã, eu pensava: mas que estranho, [risos] eu achava que esse era o trabalho do homem, o meu pai a vida inteira fez." [ri, divertindo- 
${ }^{26}$ Cineasta e crítico de cinema.

${ }^{27}$ Feminista brasileira $(1930$ 2014), escreveu, entre outros livros, Memórias de uma mulher impossível (1999).

${ }^{28}$ Foi entrevistada por Hebe Camargo, apresentadora de programas de televisão. ${ }^{29}$ Trata-se do diretor de televisão Nilton Travesso. se] Você vê... Então, como é que eu podia imaginar isso. Meu pai e minha mãe, os dois trabalhavam em casa e os dois trabalhavam fora de casa. Então não havia uma divisão, sabe? Eu não tinha nenhuma ideia disso, não podia imaginar. Para mim era uma coisa assim muito normal. Olha, eu posso fazer isso, eu não quero fazer aquilo, sabe? Era uma coisa mais assim. Eu só fui tomando consciência dessas coisas na vida prática mesmo. Aí é que eu comecei a ficar assustada.

AMV: Tereza, você vê então esse filme - e também o seu trabalho como um todo - em diálogo com o contexto, com todas essas questões do movimento feminista que eclodia naquele momento? Como você se coloca nesse diálogo?

Tा: Olha, nessa época eu comecei a pesquisar. Porque quando, em 1973, o Alex Viany ${ }^{26}$ escreveu uma matéria falando que eu era "a primeira cineasta do moderno cinema brasileiro", telefonei para ele e falei: "Mas que responsabilidade... você tem que procurar melhor". Ele falou assim: "Eu sou pesquisador" [risos]. Eu falei: "Não é possível. Eu, lá na 'boca do lixo' - porque fazer cinema em São Paulo é na 'boca do lixo'-, conheci a Aurora Duarte." Ele falou: "É, mas a Aurora Duarte, não chegou a ser diretora, foi produtora." E aí explicou tudo e eu disse: "Não é possível. Não teve a Carmen Santos?" Ele falou: "Sim, tem a Carmem Santos. Estou falando do 'moderno' cinema brasileiro." Eu assim, discutindo com ele. Aí é que eu fui pesquisar, inclusive nos arquivos dele. A Cléo de Verberena, que fez o primeiro filme em 1928, O mistério do dominó negro, e precisou vender as próprias joias para conseguir fazer o filme. A Gilda de Abreu, eu conheci a Gilda... Pinguinho de gente, O ébrio... Uma gracinha a Gilda, maravilhosa! A Carmem Santos, que foi uma mulher assim... ela criou a Brasil Vita Filmes, ela era portuguesa, mas ela fez os filmes com o Humberto Mauro, com o Ademar Gonzaga, ela criou a própria empresa. Da Inconfidência mineira [filme dirigido por Carmem] só restaram dez minutos, foi perdido o resto. Mas aí é que eu fui procurar, porque quando ele colocou "a primeira", aquilo não era possível, me deu uma sensação assim, de um vazio, de vertigem, sabe? Eu falei: "Não é possível isso. Como?" É como se fosse ser o fardo mais pesado, sabe como é? E evidentemente que foi, com essa questão da censura, com tudo isso que se interpôs.

Nessa época eu fiquei muito amiga da Rose Marie Muraro. ${ }^{27} \mathrm{~A}$ gente se conheceu nos bastidores de uma entrevista. Eu fui fazer uma entrevista com a Hebe Camargo. ${ }^{28}$ O Nilton... ${ }^{29}$ esqueci o outro nome dele, que montou todas as televisões, era o diretor do programa. Ele veio falar comigo antes e falou assim: "Mas caramba, você vai falar isso na televisão? Mesmo sendo o programa da Hebe, acho que você não pode falar assim." Eu falei: "Então, não sei o que é que eu estou fazendo qqui." O produtor do programa, que era o diretor, estava querendo ele 
${ }^{30}$ Cineasta, diretor do filme Todas as mulheres do mundo (1966), que menciono como contraposição a Os homens que eu tive. Conforme VEIGA, 2013 mesmo arrumar o meu discurso para a Hebe. Então, quando cheguei lá na entrevista com a Hebe, ele falou: "A Hebe quer que você fale." "Então tá bom." Aí cheguei, fui falando... E a Hebe: "E isso, como é que é? E qquilo, como é que é?" Aí eu fui me soltando. "Mas é isso!" Aí, a Rose Marie, que estava sentada na plateia esperando para ser entrevistada, veio conversar. $E$, por um acaso, Domingos Oliveira, ${ }^{30}$ que era muito meu amigo, nos apresentou logo depois. A gente conversou, ela disse: "Eu já sei quem é essa menina." A gente ficou superamigas.

E aí sim, o contexto... A gente, em 1975, montou a mostra da Semana do Cinema Feminino, para isso, fez um levantamento das atrizes. As atrizes, o que era feito delas, porque ser atriz é complicado. Meryl Streep fala isso até hoje, Ana Magnani falava: "Respeitem minhas rugas, que eu levei tantos anos para conseguilas." Já a Meryl Streep fala hoje: "Eu não vou ficar fazendo plástica, quero ficar parecendo o quê?" A mulher, a atriz, ela tem uma vida útil pequena. Então imagina, naquela época, a gente procurando ver a abordagem dos filmes, das mulheres, o que era feito, como é que a carreira conseguia se desenvolver... A gente até montou um coletivo feminino na época. $O$ coletivo feminino nós montamos em 79. Acho que se chamava assim: Coletivo das Mulheres de Cinema. A gente se reunia, e aí era um universo que a gente não conseguia equacionar, porque era um universo das diretoras, produtoras, até das técnicas. Naquela época você não tinha sequer creche para deixar os filhos. Quase todas tínhamos filhos. Como é que você fazia? A gente só tinha um jeito de fazer filme, né? Levando os filhos junto, não tinha outro jeito. Ou, na hora que você tinha que estar num schedule muito apertado, muito oneroso, de filmagem, você deixava o filho com a mãe aqueles dias. Monta a estrutura toda na casa da mãe, pai, e vai e filma. Então era muito complicado, quer dizer, a "condição feminina" era uma condição que você tinha que deixar ela inteira em uma nova versão, porque a versão que existia, ela te excluía de todas as formas.

Com a perseguição por parte da censura, eu tinha já um outro filme, já tinha a produção e tudo armado, e acabou tudo com a interdição de Os homens que eu tive. Era um filme que, na época, se chamava Expressamente proibido. Porque era aquela partezinha que existe e que você abre, ali, expressamente proibida, onde você tem todo o mundo das dúvidas. Então, você imagina... O produtor falou: "Imagina! Você acabou de ter seu filme [proibido], e vai fazer um filme assim?" Eu falei: "Você está lendo aqui o argumento... é comercial, não é? E ele: "Eu quero fazer, mas, escuta, já acabou. Já vai ser interditado. Você é uma 'interditável'. Agora você entrou num índex." E pronto.

Para o outro filme que eu fiz, fui contratada. Eu fui a produtora e tinha dado o título Morta, nua e sorridente. O exibidor fez com que os produtores optassem por mudar o nome para Ana, a libertina, achando que assim fosse mais comercial. Um filme com a 
Marília Pera, com José Wilker, com Daniel Filho. Então era um filmão. Morta, nua e sorridente era um policial. A mulher tinha sido encontrada morta, nua e com [faz um gesto com as mãos nos cantos da boca] dois cortes na boca, que a tornavam sorridente. Então, "morta, nua e sorridente" está dizendo tudo do filme, está colocando que é um policial... que ele terá investigação. O maior exibidor do Brasil na época disse: "Não, não, não. Esse título não tem nada de comercial." E não deixou ter esse título. Depois, eu fui convidada para fazer um filme de episódios, um filme de produtor, que era baseado no Livro negro do amor, do Marquês de Sade. Era o primeiro livro que ele tinha escrito, eram historinhas pequenas. Eu falei: "Sabe, não está me interessando." O produtor insistiu: "Eu gostaria muito..." Eu concordei: "Então, tá bom. Vou pegar quatro histórias e vou colocar quatro atores em cena, quatro personagens, cada um vai contar sua história e vai usar os outros atores. Pode ser isso?" Ele aceitou. Aí já dava para contar uma historinha: duas mulheres, dois homens, contando a historinha, passeando, andando... e eles iam usando as historinhas do livro. Então, era um filme de produtor. Pois bem, o meu episódio foi totalmente mutilado [fecha o rosto].

AMV: De novo a censura?

Tा: Totalmente mutilado. Por quê? Porque tinha um índex. Não foi cortado "aquele" pedaço... Não. O filme ficou incompreensível. E a besta do produtor, em vez de cortar nas cópias, ele cortou no negativo. Quando eu vi o filme, falei: "Mas, vem cá, o que você fez?" E ele: "Ah, eu mandei cortar no negativo, porque assim já resolvia a questão de uma vez." Eu reagi: "Então, o filme é seu, não é meu. É seu e da censura. Não quero mais saber desse filme. Esse filme é seu e da censura. Eu não fiz esses cortes, não fiz essa montagem, eu não fiz nada disso. Vocês que assumam a autoria do filme." E esse filme até foi exibido, e até foi bastante bem.

AMV: Qual que era o nome do filme?

TT: [puxando pela memória] Chamava-se Deliciosas traições do amor. Que era o Livro negro do amor... Deliciosas traições do amor. Recentemente esse produtor me mandou um e-mail: "Queria saber se você tem uma cópia do filme." Eu respondi: "Eu reneguei o filme. Por mim, se ele desapareceu, tanto faz, isso é o que eu já tinha feito com ele. Depois que você cortou... você foi uma pessoa completamente inábil como produtor."

${ }^{31}$ Versos do Poeminho do contra de Mário Quintana, criado em 1978 como reação a uma situação semelhante àquela passada pela entrevistada.
Você tem que pensar "eles passarão, eu passarinho", ${ }^{31}$ né? Daqui a pouco eles saem, eu boto o filme de volta, como o filme é, e não o filme como eles querem que seja.

AMV: Isso foi em que ano, esse filme?

Tा: Isso foi em 1975. Em 76 houve o festival de cinema de New Orleans, festival de cinema feminino, o Women's Film Festival 
32 Todos os filmes citados por Trautman são italianos, tirados de cartaz pela censura do governo democrata cristão de Giovanni Leoni (1971-1978).
${ }^{33}$ Antenne 2, canal de televisão francês, de serviço público, criado em 1975. Atualmente chama-se France 2 e faz parte do grupo France Télévisions. ${ }^{34}$ Dom Hélder Câmara (19091999), arcebispo da Igreja Católica, foi grande defensor dos direitos humanos durante regime militar no Brasil. de New Orleans, dentro de uma universidade. E a gente foi, uma comissão aqui do Brasil foi para lá. E passou Os homens que eu tive, o meu filme interditado em 73, junto com Mimi, o metalúrgico [1972], da Lina Wertmuller, Sacco \& Vanzetti [1971, de Giuliano Montaldo], A classe operária vai ao paraíso [1971, de Elio Petri], Zabriskie Point [1970, de Michelangelo Antonioni]... e uma dúzia de filmes desses. ${ }^{32}$ Eu falei: "Bem acompanhado ele está, mas acho que ninguém merece um filme estar interditado, não é?" Eram filmes que estavam em cartaz, eles foram retirados dos cinemas, tirados de cartaz. Então, em 1976, meu filme passou no festival de New Orleans, só que a Embrafilme mandou a cópia sem legendagem. Ele passou no sábado, em sessão dupla com Mimi, o metalúrgico, da Lina Wertmuller - esse com legendagem, com tudo. A plateia estava cheia e ria na hora da piada. Mesmo sem legenda, entendiase o filme. Eu fiquei tão abismada com aquilo... eu falei: "Poxa vida, que legal isso!" [sorri]

A ditadura não deixava você falar sobre a condição social. Em 1976, eu tinha o apoio da Antenne $2^{33}$ para fazer um documentário sobre o Dom Hélder, ${ }^{34}$ e estava já com a pesquisa bem adiantada, quando o representante da Antenne 2 veio e me falou: "Olha, Tereza, vamos desistir. Você já tem um filme interditado e eu fui chamado na Polícia Federal, porque eles só querem renovar meu visto aqui, de residente, se eu não ficar abordando coisas que eles não querem." Eu fiquei assim... [arregala os olhos]. Você pode imaginar? Fiquei fazendo um filme que eu pensei: vai ser para o exterior, não vai ser para o Brasil. Eu não tinha imaginado mercado para ele no Brasil. Na televisão não ia passar, então ia passar no exterior, direto. Eu falei: "Não precisa ser oficial." Ele falou: "Mas como eu vou aparecer com esse filme depois? Como que eu vou importar esse dinheiro para fazer isso?" Aí a gente ficou assim... sabe?

Eu fiz O caso Ruschi em 1977, sobre o cientista Augusto Ruschi, que na época estava com uma reserva florestal, comprada com o dinheiro dele e doada à Universidade Federal do Rio de Janeiro para transformar em reserva biológica, era a Reserva Biológica de Santa Lúcia, no Espírito Santo. O governo do estado sumiu com a papelada - até o cartório tinha pegado fogo - e criou o Instituto Estadual de Floresta, para autorizar uma empresa japonesa a explorar palmito na reserva. Nós fomos lá, acompanhando a primeira caravana ecológica. Foi um jornalista tupinambá, lá no Espírito Santo, que levantou a história. O Jornal do Brasil publicou e eu, lendo as matérias, entrei em contato com todo mundo. A primeira caravana ecológica, imagina... eram só professores, alunos muito interessados - poucos, né? Um ônibus, umas kombis, uns carros, então a caravana era uma coisa assim, uma gente idealista... e nós conseguimos, com essa caravana, esse documentário, sustar esse processo, defender a reserva. E a Embrafilme, que ia produzir o filme, não produziu, porque estava 
${ }^{35}$ Os Saltimbancos é um musical infantil com versão em português e músicas adicionais de Chico Buarque de Holanda. no meio da ditadura e eles não queriam. Imagina, era o governo do estado... [sorri]. Então a Embrafilme pegou o filme e colocou na mostra "Brasil, 80 Anos de Cinema", que correu o mundo - o filme está dentro da mostra - e fez contratos. O filme foi exibido, ganhou prêmios em Salvador, na jornada do Guido Araújo, em Brasília, no Festival de Brasília, o Festival JB que existia na época... Então o filme ganhou prêmios em todos os lugares e não teve nenhuma carreira comercial. Quando foi? Em 78, 79... [puxando pela memória] 78.

Eu comecei a fazer Os saltimbancos, ${ }^{35}$ o musical infantil. E fui para a Embrafilme, o Gustavo Dahl era o superintendente de comercialização: "Maravilha! É um filme assim que a gente quer. Maravilha, infantil, beleza! De quanto você precisa? Eu olho para você, eu vejo a efervescência, o olho alucinado do cineasta já esquentando as turbinas."

AMV: Começou a sair do índex?

Tा: Ele já assim:"Vamos lá fazer." Eu digo: "Está aqui o roteiro, está aqui o orçamento..." Aí bateu na diretoria geral, era o Roberto Farias. Roberto Farias olha para mim e diz: "Tereza, você já fez um filme interditado. Chico Buarque, um sujeito interditado. Tereza, uma mulher que tem filme interditado. Eu não posso colocar dinheiro da Embrafilme num filme que vai ser interditado, vai ter problemas com a censura." Eu escutei isso. Depois que ele saiu da Embrafilme ele fez o filme Pra frente Brasil. Então, eu sei porque ele falou isso para mim. E, com muita pressão, eu consegui depois um dinheiro que era uma parcela mínima, uma parcela que não deu para dar a partida no filme, porque era um musical... Você tem que pegar os atores, ensaiar os atores, gravar a música com eles cantando, para você ter o playback para durante a filmagem não ficar nada fora de sincronia, para eles poderem dançar e tudo, é assim que se faz um musical. Então você imagina...

Em 1984, a Anistia Internacional fez um festival de filmes proibidos em Toronto, no Canadá, e Os homens que eu tive foi o Gala Opening Night [sorri, satisfeita]. Aí foram os filmes proibidos da história do cinema, sabe? Um festival muito legal! E até aconteceu uma coisa muito engraçada. A censura do Canadá interditou, proibiu a exibição de alguns filmes. Não o meu, que já tinha sido exibido. Mas chegou a proibir Saló, do Pasolini... eu não me lembro de todos os filmes. E vieram me entrevistar, porque eu tinha feito o Gala Opening Night: "E você?" Eu disse: "Como? Eu venho para um festival da Anistia Internacional, eu que moro num país que está sob uma ditadura..." Era 1984. "...chego aqui, meu filme é exibido, discutido... e a outros filmes do festival eu não consigo assistir? Eu tenho curiosidade de assistir, porque no meu país esses filmes não estão passando, e não posso? Como é isso? Esses filmes não passaram comercialmente antes? Como 
é essa discussão? Por onde passa?" Bom, virei celebridade nacional assim, eu discutindo a censura do festival da Anistia Internacional, lá no Canadá. Aí me chamaram para ir para Montreal exibir meu filme lá, no National Film Board. O pessoal enlouqueceu com o filme. Uma cineasta, que tinha ganhado o Oscar com um curta-metragem, a Beverly Shaffer, falou com o Jack Bensimon, que era o diretor geral do National Film Board. Ela me disse: "Vamos lá, que o diretor geral quer falar com você, quer te conhecer, e eu gostaria de te acompanhar, posso?" Eu falei: "Lógico, vamos." Quando chegamos lá para falar com ele, ela disse assim: "Eu gostaria de ir para o Brasil, aprender a fazer cinema com ela." Ela tinha ganhado o Oscar. Na frente do diretor falamos assim: "Mas por favor... Eu não vi seu filme, mas você ganhou um Oscar..." Ela falou: "Não, eu quero aprender a fazer cinema com ela." Eu falei: "Olha, muitas coisas para mim são novidade aqui, primeiro porque eu não podia imaginar que cineasta aqui trabalha com cartão de ponto. Eu vi eles batendo ponto para chegar, batendo ponto para sair... Eu não posso imaginar. O roteiro você escreve em determinadas situações, no colo, anota em qualquer lugar, comendo, falando com uma pessoa no telefone e está escrevendo um outro negócio, não posso imaginar que você tenha uma hora marcada: nine to five, você senta lá e escreve, sai naquela hora. Eu acho que eu não iria conseguir escrever assim." Eu já estava apavorada. E ela: "Eu quero fazer, sim, eu quero fazer um filme... Do que você precisa?" Eu falei: "Olha, seria ótimo se vocês trouxessem equipamento, negativo..." Ela disse: "Dinheiro a gente não tem para custear. A gente mandaria uma equipe básica". "Do que é que você precisa?" (disse o diretor, desta vez para a cineasta). "Eu quero uma equipe básica, eu quero um produtor, um fotógrafo, quero um montador, porque, mesmo se a Tereza não quiser, eles vão me acompanhar, porque sem eles estarem sabendo como isso funciona, a gente não vai conseguir implantar isso aqui." Bom, você pode imaginar... aqui no Brasil...

Depois eu saí de lá, fui para Nova lorque, chegou um pessoal do consulado, e disse: "A gente tem ouvido falar de você. Você não acha perigoso isso que está fazendo? Eu falei: "Mas a ditadura no Brasil tem que cair, não pode continuar." Isso era novembro de 1984. Eu falei isso num jantar, tá? Disseram: "Não, mas isso é extremamente perigoso! Você já viu essa gente, Paulo Maluf, Mário Andreazza, você já viu eles perderem alguma? Eles não perdem. E aí você vai estar o quê? Comprometida." Eu falei: "Como eu estive a minha vida inteira." E eles: "É, mas você está tendo cada vez mais projeção e isso é perigoso para você." Eu falei: "Ou pode ser o salvo-conduto, pode ser o que vai me salvar nessa hora, não é?" Bom, eu sei que eu fiquei tão furiosa com aquilo... - mas não furiosa assim de falar: "Ah, por que é que ele está falando?" Furiosa com a situação, sabe? Tanto que comecei a falar para os jornalistas: "No Brasil, a gente está vivendo um 
${ }^{36}$ Em 1984, haveria eleição para a presidência, mas seria realizada de modo indireto, através do Colégio Eleitoral. Os candidatos indicados eram Paulo Maluf (PDS) e Tancredo Neves (PMDB) momento histórico. Você tem que ir para o Brasil, fazer essa cobertura." Todo jornalista que vinha me entrevistar, eu falava: "Você tem que ir para o Brasil fazer a cobertura desse momento histórico que a gente está vivendo." [sorri] Pensei: vai ter que ser colocado o momento... porque a votação ia ser por voto indireto, pelo colégio eleitoral. Só que eram dois candidatos, ${ }^{36}$ era aquela coisa toda pré-estabelecida, mas se você bota uma projeção internacional nisso, você obriga a coisa a ter uma certa formalidade. E aí aconteceu tudo o que todo o mundo sabe. Mas jornalistas internacionais vieram e fizeram uma ampla cobertura. Então, eu acho que isso tudo... foram momentos em que minha carreira teria sido outra, minha vida teria sido outra, tudo teria sido diferente, não é? Como a do país. O país vive hoje [em 2010] ainda um hiato de falta de líderes. Porque nós temos no Brasil uma mídia... os senhores da mídia no país são o que há de mais atrasado que pode existir. São pessoas que não admitem nenhuma mudança social no país.

AMV: Isso é verdade.

Tा: Então eles imprimem uma forma de o país ser, de o país conhecer a si próprio, que é mentirosa.

AMV: E sobre o seu último filme?

TT: O Sonhos de menina moça, foi em 1987. Em 88, o filme foi convidado para mais de 20 festivais internacionais. Foi uma coisa assim... Eu acho que o filme tem uma abordagem muito complexa, porque ele procura pegar o que o país passou... Os sonhos são dessa juventude de 1945, a construção de 1946 foi escrita por essa geração, é a geração dos pais, dos avós, não é? Os filhos desapareceram, morreram, foram perseguidos na década de 60/70... O filme é passado no momento atual, em 1987, embrulhando essa vida, que é uma vida que foi conformada por esse mundo. Então, o sonho da geração de 1945/46, de construir um mundo, o sonho da geração de 1960 de modificar o mundo, de construir um outro mundo e a geração na década de 1980 pegando a elite, pegando o mundo dos empregados, pegando essas três gerações e as diferentes classes sociais. Porque os empregados moravam junto, então é lógico que essa família criava os filhos dos empregados junto com os filhos dela, não iam criar uma segregação em casa. E todo mundo começa a reviver o que viveu, seus sonhos... É o último dia da família na casa onde se passaram todos esses anos, todos esses momentos, todas essas histórias. Então eu acho um filme muito complexo. Depois de tanta interdição, é como se eu tivesse muita coisa para falar ao mesmo tempo. O filme foi muito bem recebido fora do Brasil, recebeu três estrelas e meia de críticos, num máximo de quatro estrelas, nos Estados Unidos, no Canadá, na Inglaterra. Eu tenho diploma de vários lugares. Foi lançado aqui no Brasil em 1989, a gente já estava vivendo um processo difícil para o 
cinema brasileiro. Meu agente de vendas era o mesmo dos filmes do Truffaut em Nova lorque, porque ele viu o filme e falou: "Esse filme é maravilhoso. Eu sei cuidar desse tipo de filme." Eu abri uma filial da minha empresa nos Estados Unidos, tinha a Miramax interessada em distribuir e coproduzir meu próximo filme; a Embrafilme tinha feito contrato comigo para desenvolver o projeto, visando a distribuição e a coprodução. O filme se chamava $E u$, como você, eu igual a você, né? Aí veio o Collor, tudo isso se acabou, e nos Estados Unidos eu tive que usar o motivo de força maior, por não ter como honrar contratos que eu tinha assinado. Então foi uma catástrofe, que nós...

AMV: Tiveram que engolir, não é?

Tा: O Brasil não merecia...

AMV: E nesse filme, Sonhos de menina moça, você traz, uma vez mais, muito fortes as personagens das mulheres. Fale um pouco disso.

Tा: Tem a mulher que é a mãe, o pai era o juiz - eles que são da geração de 1945 -, eles tiveram três filhas mulheres e um homem, que foi torturado e desaparecido, nunca mais conseguiram encontrar. A Marieta Severo faz a filha do empregado e, nesse dia, ela acha uma roupa de gala, que veste, e começa a beber na festa à noite, entendeu? Então são as mulheres... porque as mulheres é que fizeram ou sofreram ou ficaram com o drama da história toda. Então, realmente, "sonhos de menina moça" mostra os sonhos que as mulheres tiveram e foram elas que ficaram, porque os homens foram desaparecendo, morrendo.

AMV: E os diálogos são muito interessantes, das angústias e dos sonhos mesmo, das mais velhas, as gerações vão falando ali... Tा: É... O filme participou do London Film Festival, do Toronto Film Festival, do Miami Film Festival... Sabe, com críticas que se você ler, você diz "Meu Deus do céu..." Sabe, as pessoas... comparando cineastas a cineastas, sabe aquela coisa assim? Então eu acho que é um filme que me abriu a carreira internacional, só que eu não consegui sustentar, porque eu não tinha dinheiro para comprar pão e leite para os meus filhos aqui. Eu literalmente não tinha como botar comida dentro de casa. Essa foi a situação que o Collor deixou. Minha mãe, que era aposentada, minha mãe teve que me emprestar dinheiro para eu poder comprar pão e leite. Eu me lembro tão bem disso...

AMV: O que é que adiantou tanta projeção, não é?

Tा: [rindo] É, e aí eu tive que fechar minha empresa, porque a empresa nos Estados Unidos era uma filial da empresa brasileira e aqui eu não tinha condição de continuar. 
AMV: Deixa eu perguntar uma última coisa, o que você acha que foi mais representativo dessa geração de cineastas, como você, a Helena Solberg, a Ana Carolina? Qual a sua opinião sobre essa geração, sobre essas cineastas?

Tा: Olha, eu acho que todas nós fizemos filmes de menos. Todas nós ficamos com mais projetos, com mais vontade de fazer filmes do que conseguimos fazer. Acho que houve muitos filmes que ficaram somente na ideia - o que é uma grande pena, porque é uma cinematografia tão diversa. Você vê Ana Carolina, Tizuka Yamazaki, Suzana Amaral... Filmes maravilhosos e cada filme diferente um do outro. Você imagina, se tivesse havido condições de se filmar à vontade, o que é que não seria, o que é que a gente teria conseguido fazer? Quantos filmes? "Cineastas amordaçadas" - talvez seja esse o título para toda essa geração, a toda essa leva de mulheres. Ainda bem que hoje em dia tem muitas mulheres fazendo. A primeira cineasta da retomada foi uma mulher, foi uma primeira cineasta (Carla Camurati). Aliás, você sabia que a primeira filósofa no mundo foi uma mulher?

AMV: Ah é?

Tा: Mas isso a gente fala numa outra vez. Só porque a gente olha e pensa em como a "condição feminina" ficou tão complicada. Eu acho que nós deveríamos ter mais mulheres fazendo mais coisas, inclusive porque há observações, há um olhar feminino, que fica fazendo falta; quando você não tem numa cinematografia, você precisaria ter. Então imagina quanta coisa que faz falta, quanta coisa que não foi feita no meio disso, não é?

\section{Referências}

KOSELLECK, Reinhart. Futuro passado: contribuição à semântica dos tempos históricos. Tradução de Wilma Patrícia Maas e Carlos Almeida Pereira. Revisão da tradução de César Benjamin. Rio de Janeiro: Contraponto/Editora PUC-Rio, 2006.

LAURETIS, Teresa de. Figures of Resistance. Essays in Feminist Theory. Edited and with an Introduction by Patricia White. Illinois: University of Illinois Press, 2007.

ORTNER, Sherry. "Poder e projetos: reflexões sobre agência". In: GROSSI, Miriam Pillar; ECKERT, Cornélia; FRY, Peter (Org.). Conferências e Diálogos: saberes e práticas antropológicas. Blumenau: Nova Letra, 2006, p. 45-80.

RAGO, Luzia Margareth. A aventura de contar-se: feminismos, escrita de si e invenções da subjetividade. Campinas: Unicamp, 2013.

RICOEUR, Paul. A memória, a história, o esquecimento. Tradução de Alain François. Campinas: Unicamp, 2008.

SMELIK, Anneke. And the Mirror Cracked. Feminist Cinema and Film Theory. Wiltshire, GB: Macmillan Press LTD, 1998. 
VEIGA, Ana Maria. Cineastas brasileiras em tempos de ditadura - cruzamentos, fugas, especificidades. 2013. 397 f. Tese (Doutorado em História) - Programa de Pós-Graduação em História, Universidade Federal de Santa Catarina, Florianópolis, 2013.

[Recebido em 31 de janeiro de 2015 , e aceito para publicação em 22 de abril de 2015]

\begin{abstract}
A History of Cinema and Censorship during Brazilian Dictatorship: Interview with Tereza Trautman

Abstract: Filmmaker Tereza Trautman's work was crossed by the emergency of emancipation and equality for women vindications, mainly in the 70's. While Brazilian military government and its censorship organism tried to moralize society and to keep women in their private role traditionally established, Tereza Trautman took the camera and sought to create new representations for them into the cinema. In a radical way, her work acquired agency, questioning in an irreversible way women's place, in the purpose of a new society. The censorship scissor crossed definitely her carrier and the director saw, one by one, her professional projects sinking down. Os homens que eu tive, her more polemic film, is in the main stream of this interview, which opens a space to a narrative that is also an outflow of a women's generation which looked for professional survival and expression strategies during the Brazilian dictatorship years.

Key Words: Tereza Trautman; Os homens que eu tive; Cinema; Dictatorship.
\end{abstract}

860 Estudos Feministas, Florianópolis, 23(3): 839-860, setembro-dezembro/2015 